\title{
Anlam Arayışlarında Özne-İnsan'a Dair Günümüz Akademik Sosyo-Kültürel Yaklaşımların Felsefi Bir Kritiği: Türkiye Örneği
}

\section{A Philosophical Critique of Academic Current Approaches to a Subject-Human in Meaning Inquiries: Turkish Sample}

Hacı Mustafa Açıöz a,*

${ }^{a}$ Doç. Dr., Muş Alparslan Üniversitesi, Fen Edebiyat Fakültesi, Felsefe Bölümü, 49250, Muş/Türkiye. ORCID: 0000-0002-7998-2742

\section{MAKALE BILGISI}

\section{Makale Geçmişi:}

Başvuru tarihi: 10 Temmuz 2020

Düzeltme tarihi: 13 Ağustos 2020

Kabul tarihi: 04 Eylül 2020

Anahtar Kelimeler:

Anlam-arayışları,

özne-insan,

özne-insan kozmo ontolojisi,

felsefe, akademia.

\section{ART ICLE INFO}

\section{Article history:}

Received 10 July 2020

Received in revised form 136 August 2020

Accepted 04 September 2020

\section{Keywords:}

Meaning inquiries,

subject-human,

subject-human cosmo-ontology,

philosophy, academia.

\section{ÖZ}

$\mathrm{Bu}$ makalede günümüz akademik bazı olgusal örneklerden yola çıkarak ister mensubiyeti sıradan halka ister akademiya'ya ait olsun bilgi ve anlam arayıcısı insanların kendi yaşanmışlıklarından hareketle bilgi faaliyeti öznesine (özne-insana) karşı sergilediği sıradan veya akademik sosyokültürel yaklaşımların olgusal bir resmini çekip nazari ve ameli seviyelerde kozmo ontolojik çerçevede felsefi bir kritiği yapılacaktır. Kaldı ki, bilgi faaliyeti sürecinde insanın kendisi bu eylemin: hem aktif öznesi; hem edilgen nesnesi; hem de bazı durumlarda (özne+nesne) her ikisi konumundadır. Amacımız, makale konumuza dair genel düşünsel çerçevenin yanı sıra bilgi ve anlam arayıcısı insanın içinden şekillenip çıktığı ve ölümüne kadar içinde olduğu halk sağduyusu, kültürü ve bilgeliği tecrübi verilerinden hareketle kısaca bizim Türk akademiya'sının durumunun tespit ve değerlendirmesini yapmaktır. Sonuçta özne-insan merkezli bilgi ve anlam arayışların da özgünlük ve özgürlük adına elimizde neyin olup olmadığına şahit olacağız.

\section{A B S T R A C T}

In this paper, we shall pursue a philosophical critique of the current academic approaches to a subject-human in knowledge and meaning inquiries both theoretical and applied levels at the cosmo ontological ground by applying the views of ordinary persons and academicians who run after knowledge and meaning inquiries so as to obtain factual pictures of the topic. In the end, by means of the paper we shall be witness of the fact that whether or not there are any originality and free-thinking about the subject-human centred knowledge and meaning inquiries among Turkish academicians.

\section{Giriş}

Genelde düşünce, özelde bilgi/bilim tarihinde bilgi arayışı faaliyeti insan tarafindan bir merak etme, araştırma, soruşturma, inceleme konusu veya inceleme nesnesine bağlı olarak yapılmıştır. Bu faaliyetin gereği nazari, ameli veya nazari+ameli ihtiyaçlardan doğmuştur. Arayışın temel güdüsü/dürtüsü/gayesi insanın kendisinin ve çevresinin doğal ihtiyaçlarını giderme zarureti, merak, bilme, anlama ve anlamlandirma arzusudur denilebilir. Anlam ve bilgi arayışlarında özne-insan ister farkında olsun ister olmasın her bilgi faaliyetinde aslında kendini, diğerlerini, doğayı, evreni ve Yaratıcıya dair anlam arayışların da bulunmaktadır. $\mathrm{Bu}$ arayışın gerekliliği hatta zorunluluğu insanın doğası, yapısı ve donanım özelliklerinden kaynaklanmaktadır. Bu yapısal zorunluluğa insan istese de kayıtsız kalamaz. (Hume, 1989) Nitekim düşünce tarihinde kinikler ve şüpheciler bile kayıtsızlıktan dem vurmalarına rağmen gerçekte hem düşünsel nazari seviyede hem de uygulamalı hayat pratiğinde kayıtsız kalamamışlardır. Öztürk'ün de belirttiği gibi: "Esasen bir ölçüde nihilistlerin ve anarşistlerin itirazları dahi onto-epistemik bir meşrulaştırma ihtiyacından doğmaktadır." (Öztürk, 2019:

\footnotetext{
* Sorumlu yazar/Corresponding author.

e-posta:m.acikoz@alparslan.edu.tr
} 
189) Çünkü kayıtsız kalmak varoluşuna ve varlıktalığına küsmek demek olacağından bu bütünüyle mümkün değildir.

$\mathrm{Bu}$ süreçte anlam ve bilgi arayıcısı özne-insan bazen kendisini de arayış, inceleme ve soruşturma konusu edinmektedir. Edinmek de zorundadır. (Ryle, 1976) Çünkü kendi benliği hakkında farkındalığı olmayanın kendi dışındaki diğerlerine/ötekilerine dair de farkındalığı/bilgisi olamaz. (Shoemaker, 1972; Madden, 1983; Kierkegard, 2017) Nitekim bu farkındalığa/şuurundalığa en yüksek seviyede sahip olan tek varlık insanın ta kendisidir. (Reid, 1969a; 1969b; and 1970) Fakat çoğu zaman insan bu donanım ve özelliğe sahip olmasına rağmen onu çeşitli rasyonel veya irrasyonel sebeplerden dolayı işlevselleştirmezler. Böylece alık ve balık durumuna düşerler, adeta "Cihân ârâ cihân îçindedir ârâyı bilmezler

O mâhîler ki deryâ içredir deryâyı bilmezler" derya içinde olmasına rağmen sözünü inatla ispat etmek istercesine. Bu arayış sürecindeki soru ve sorun "özne-insan”a yüklenen materyalist/pozitivist, spiritualist/idealist veya materyalist+spiritualist içerik ve işlevden kaynaklanır. Gerçekte insan "özne-insan"a rol biçerken veya tayin ederken kendi kendine rol biçmektedir. Yani, "özne-insan" dair getirilen bakış açısı/yaklaşım otomatikman insanın da içerik ve işlevini belirlemektedir. Tabi ki bu içerik, iş, işlev ve önem “özne-insan”ın uğraş alanına da aynen değer olarak yansımaktadır. Öyleyse insanın ontolojik yapı ve özellikleri “özne-insanı” 1 belirlemektedir.

Örneğin, sosyal bilimlerde ve felsefede “özne-insan"ın ontolojik statüsü indirgemeci anlayış ve uygulama ile belirlenmişse statü eksik ve parçalı olup insan bütününe karşılık gelemeyecektir. Bilgi ve bilimin her alanlarında anlam arayışlarında “özne-insan”a dair ana problem maalesef işte tamda buradan kaynaklanıp tarihi bir süreklilik arz etmektedir. Düşünce ve bilim tarihlerinde sözde felsefe, bilim ve din eksenli ideoloji ve dünya görüşleri çerçevesinde “özne-insan”a indirgemeci rol biçilmektedir. Antik Yunan ve Hellenistik Roma ağırlıklı olarak materyalist indirgemecilik yarı tanrı-insanlığı, Hristiyan batı ortaçağ kilise hâkimiyeti maharetiyle spiritualist ağırlıklı indirgemecilik tanrıya kulluğu, modern çağ ve aydınlanma dönemlerinde sözde akıl eksenli materyalist/pozitivist indirgemecilik insan-tanrıcılığı, postmodernite döneminde hiçcilik ise ölümsüz tanrıyı öldüren ölümlü insan-tanrıyı kendi karakteristikleri olarak benimsemişlerdir.

Çoğunlukla fen ve doğal bilimlerde kullanılmasına rağmen indirgemecilik adeta bilim patentli bir ideolojiye dönüşmüştür. (Ayer, 1969) Batı dünyasında ircacı düşünce ve uygulamanın temelinde Antik Yunan görülmekte olup Avrupa başta olmak üzere günümüz batısı kendini onların mirasçısı olarak iddia etmektedirler. (Sorley, 1951) İndirgemeci bu merkez eksenin yanı sıra bir de taşeron, bayi ve tetikçi uydu Yunandışı Yunansever düşünce ve kültür çevreleri söz konusudur. Bunlar gönüllü ircacı Yunan kıyakçıları ve yancılarıdır. Unutulmamalıdır ki Yunan veya Batı kıyakçılığındaki gönüllülük süreçte ayakçılıkta da gönüllülüğü gerektirir. Her ne kadar "el erkiyle gerdeğe girilmez" ilkesi genel geçer olsa da bu anlayış el erkiyle gerdeğe girmeye doğal zemin hazırlar. Dolaysıyla doğan çocuğun yarısı elin olacaktır. Bir insan el erkiyle gerdeğe onu sevdiği, benimsediği veya ona hayran olduğu için girer. Lakin günümüzde arzu, tutku ve sevgi anlık yaşanan heva heves ürünü olduğu için kurala, kuruma, örfe ve adete bağlanmaz. Böyle bir anlayış ve uygulamada evlilik diye müessese olmayacağından gerdekte olmaz.

İlk seküler, teorik, özgün ve bilmek için bilmek güdüsüyle felsefe ve bilimin Yunanda yapıldığı ve bu süreçte Yunandışı düşünce ve uygarlık çevrelerinden yardım alınmadığı tezi kahir ekseriyetle Batı ileri sürülüp adeta iman durumuna taşınmıştır. Peki, Yunan düşünce çevresinde özel olan nedir? Bu soruyu inceleme konumuz açısından kısaca ele alarak, sonucun bizi nasıl bir ontoepistemik çerçeve ve özne-insan anlayışına götürdüğünü görelim. Yunan düşünce çevresindeki kavramsal kodlarla ifadesi şudur: theoria (nazariye), technee (ameliye), theoria (nazariye)+technei (ameliye) formülüdür. Bilgi eylemindeki bu sonuçsal gerekçe alanlarını besleyen kavramlar ise: skepia/skepsis (şüphe); doxa (sanı); pistis (inanç/iman); episteme (bilgi); ve praxsis (uygulama) dir. Bunlara: anthropos; cosmos, deity, nous; on vb. kavramlarını da ilave ettiğimizde kadim Yunan bilgi faaliyetinin genel kavramsal enstrümanlarını ifade etmiş oluruz. (Açıköz, 2019c)

Yukarıda da ifade edildiği gibi daha başlangıçta Yunan üzerinde durmamızın sebebi maalesef bugünkü düşünce, bilgi, bilim faaliyetlerinin temeli olarak görülüp ve bu temelin adeta bir bilimsellik patentli küresel bir ideolojiye ve bireysel seviyede ise bilimsel bir dünya görüşüne dönüşmüş olmasıdır. Postmodernist ifade ile bu yaklaşım ve uygulama pozitivist/materyalist bilim kilisesi nazariye ve ameliyesinin bir ürünüdür. Tarihsel gerçeğe aykırı bu manipülatif dönüşümde eğitim mekanizmasının kullanımı sonucu artık maalesef kurumsallaşmıştır.

Hatta insanlığın akıl hamaliyeliği tarihi adını verip bünyesinde insanın bütün zihinsel, ruhsal ve fizyolojik süreçlerinin gerek özne (etken) gerekse nesne (edilgen) konumlarında işlevselleştirerek ortaya koyduğu genelde bilgi/düşünce tarihi özelde ise felsefe ve bilim tarihleri ile bunların alt tarihleri oluşum ve anlatısında bu manipülatif kurumsal mekanizma ve araçları kullanılmaktadır. $\mathrm{Bu}$ manipülasyon örgülü alt dallara sosyal felsefe, sosyal Darwinizm, İstatistik, demografi, fiziki coğrafya ve filolojileri misal olarak verebiliriz. $\mathrm{Bu}$ ideolojinin sloganı şudur: düşüncenin, bilginin, bilimin kökensel inşacısı Yunandır ve Avrupa milletleri de kendilerini Yunanla kökenleştirdikleri için modern ve çağdaş inşacı mimar ve mühendisler de Avrupalılardır. Daha özce ifadesi: uygar insan beyaz olan insandır, beyaz olanın da Yunan mirasçısı Avrupalı olanıdır. Yani Yunanlı, Alman, Fransız, İngiliz ve benzerleridir. $\mathrm{Bu}$ bilimsel yaftalı kurumsal ideoloji öyle güçlü manipülatif özelliğe ve ideologları da mahirliğe sahiptir ki, felsefe ve bilim köken olarak kendilerine irca edilmesine rağmen sahiplenilip kullanılmakta bugünkü Yunanlılar bile gölgede bırakılmıştır.

Öte yandan küresel seviyede bu Yunancılık/Avrupacılık ideolojisinin diğer bölgelerde de kurumsallaşıp muhkemleşmesinin ana aracı olan eğitim mekanizmasının (Öztürk, 2018) hem nazari hem de ameli alanlarda işlevselleştirilme yerleri üniversiteler gibi eğitim kurumlarıdır. Ayrıca bunlara destek unsurları olarak geçmişte ve günümüzde çeşitli Kraliyet/Ulusal Akademiler, Sivil Toplum Kuruluşları (Dernekler, Sendikalar ve Lobilerini) sayabiliriz. İnsanlık tarihinin düşünce ve bilgi faaliyetinde belli dönemde gerçekleşen Yunan katkısını göz 
ardı etmek akli ve ahlaki değildir ancak düşünce ve özellikle bilgi faaliyetinin kolektif, kümülatif ortak ve çoklu bir faaliyet olduğu tarihsel gerçeğini de inkâr etmek aynı derecede akli ve ahlaki değildir. Çünkü doğal ve sosyal bir gerçeklik olarak düşünce/bilgi/bilim çevreleri birbirlerini etkilerler. Nitekim etkilenme insanın ve oluşturduğu toplumsal yapılar ve donanımları gereği kaçınılmazdır. İnsanın sosyal bir hayvan olarak nitelenmesinin bir çıkış noktası da bu yaşanmış tecrübi gerçekliktir.

Ayrıca yine unutulmamalıdır ki güçlü olan cazibe merkezi olup diğer insanları hemen hemen hayatın her alanında sözde, gözde, özde ve eylemde etkiler. Bu genel içeriği özel alanda ülkelere de uyarlayabiliriz. Soru şudur: bir ülke kendini bu anlam ve bilgi arayışında hangi dünya görüşü ile nereye yerleştiriyor? Sorunun cevabının verilmesi için söz konusu ülkenin kendi etini budunu, artısını eksisini nazari ve ameli bir teraziye vurup darasını alıp buna dair bir değil binlerce hesap kitap yapması gerekiyor. Yani, küresel ve bölgesel seviyelerde genel düşünce ve bilgi faaliyetine kendisi olarak ne kadar katkı sunmuştur? Yok eğer anlam ve bilgi arayışları yarışında üretici ülke değil de tüketici çevre uydu ülke ise güçlü olanın taşeronluk ve bayiliğini yapmaktan başka çaresi yoktur. Çaresizdir çünkü usu, eli, özü, sözü, eylemi, erki ve hatta bazı durumlarda mevcudiyeti bile onların insaf, vicdan ve aklına mahkûmdur. (Detaylı bilgi için bakınız Açıköz, 2019)

Güç sahibi merkez ülkelerin muhatabı olarak çevre veya uydu ülkelerin düşünce ve bilgi ambarı, kileri, deposu, vitrini ve en önemlisi mutfağı olarak işte tam da burada devreye üniversiteler girmektedir. Aslında bir ülkenin üniversitelerinin durumuna bakarak ülkenin geçmişi, şimdisi ve geleceğine dair en azından genel bir fikir elde edilebilir. Üniversite gerçekten hem nazari hem ameli seviyelerde anlam ve bilgi arayıcısı, tarayıcısı, araştırıcısı, soruşturucusu üretkenler topluluğu ise ülkeyi oluşturan toplumda üretkendir demektir. Çünkü nazariye ile ameliye birbirlerinin öncül ve ardılları olarak birlikte yürümelidirler. Bunun malum günümüzdeki ifadesi "üniversite-sanayi işbirliğì"dir.

Peki bu durum karşısında bizim Akademiyamız geçmişte ne yapmıştır ve şimdide ne yapmaktadır? Maalesef köklü bir düşünce kültür ve medeniyetine sahip olup bu medeniyetin dinamik bakiyesi olmasına rağmen bu dinamizmi uydu ve taşeron düşünce ve bilgi ülkesi olarak merkez ülkelerin menfaatına kullanmaktadır. Karşılığında bir iki unvana, aferine ve onlarla birlikte kurumlarında bulunma kabulüne fittir. Zaten çoğu akademisyen üniversiteleri ekmek kapısı olarak görmektedir. Maalesef mevcut durumda bu görünün uygulamada kabul görüp kökleştiğini göstermektedir. İşte bu yüzden olsa gerek ki çoğu başarılı öğrenci maddi ve manevi dürtülerle merkez ülkelere gitme arzusunu taşıyıp oralara gitme imkânlarını araştırıp oralarda kalma telaşındadır. Nitekim yurtdışına devlet bursları ile gönderilen öğrencilerin bazıları kendi ülkelerine dönmek istememektedir. Uydu ülkelerin ilgili kurumları da bunların farkında olup çeşitli maddi ve manevi vaatlerle geri döndürmeye çalışmaktadır. Malum bilgi bir güç kaynağı silahtır ve unutulmamalı ki bu durumların pek çok sebep ve gerekçeleri mevcuttur. (Açıköz, 2003b)

Öte yandan bu gerçekliklere rağmen bu durumun bir anormalite olup bir kader ve yazgı olamayacağına dair ciddi bir farkındalık oluşmaktadır. (Ahmad, 2016) İlginçtir düşünce, bilgi ve bilim pazarlarındaki anormalite ve sapkınlıklara ilişkin uyanış ve şuurundalık hocalarından ziyade özellikle felsefe ve sosyal bilimler talebelerinde gözlemlenmektedir. Çünkü onlar başka düşünce, bilgi, bilim, kültür ve medeniyet çevrelerinin başarı ve buluş hikayelerini dinlemekten usanıp "bizim hiç mi kendi model insanımız, ürünümüz ve bir başarı öykümüz yok mu?” diye sorarak, böylece, "el erkiyle gerdeğe girilmez" ve "elden gelen öğün olmaz o da vaktinde bulunmaz" deyişleri muhtevalarının farkında olduklarını göstermektedirler. Tabiî ki bu şimdi ve gelecek adına son derece sevindirici bir durumdur. Buna doğal ve aktif "özne-insan" bilincinin uyanışı, silkinişi veya dirilişli demek mümkündür.

Çünkü burada bireysel ve toplumsal hayatlarının ve o hayatları anlamlı kılan bilgi ve düşünce faaliyetlerinin öznesi olma arzu ve iradesi görülmektedir. Bireyin veya bireylerden oluşan toplumların hayatlarının bedensel, zihinsel ve ruhsal kontrol mekanizmaları kendi ellerinde değilse o hayat gerçekte onların öznesi olduğu hayat olmayıp aksine nesnesi/edilgeni oldukları başkalarının hayatlarıdır -tıpkı taşıyıcı annelik örneğindeki gibi. Yani, onlar aktif "özne-insan” olmayıp, aksine edilgen "nesneinsan" olacaklardır. Oysa bütün insanlık kendi çağlarının müstakbel homo Muslimus adayları olarak aktif "özneinsan" ’n dibi ve köküdürler ki zaten yaratılma gerekçeleri de budur. $\mathrm{Bu}$ yüzden insana hem tarihin hem de bireysel hayatının özne-insanı olması için ontolojik olarak ona beden ve can verilmesinin yanı sira akıl, irade ve vicdan içeren "ruh" ilavesi de yapılmıştır. İnsanı ayrıcalıklı kılan da bu ruh üst yapısı ve öğelerinin işlevidir. (Açıöz, 2019)

Yukarıda da kısmen belirtildiği gibi felsefe ve sosyal bilimlerde anlam ve bilgi arayışında "özne-insan"ın ontolojik ve onto-epistemolojik konumuna dair açıklama genelde iki metodik yaklaşımdan hareketle yapılmıştır. Bunlar: "Özne-insanı" ya "bedensel" ya da "ruhsal" yönüne irca eden indirgemeci; ve onun "beden+ruh birlikteliği" ile değerlendiren bütüncü yaklaşımlardır. Özelde bu iki ana yaklaşımın değişik tonajlarını görmek mümkündür. Tarihsel süreçte ircacı ve bütüncü yaklaşımlardan hareketle Doğu ve Batı'da pek çok filozof, sosyal bilimci ve hatta doğa bilimcileri özne-insana dair teori veya sistem biçimlerinde çeşitli açıklamalar yapmışlardır. Bunların zihinsel modu şu dört pozisyondan birini karşılık gelmiştir: a) İndirgemeciliği tehlikeli gören bütüncüler; b) indirgemeciliği tehlikeli görmeyen indirgemeciler; c) indirgemecilik ve bütüncülük arasında kalan aradakiler; ve d) her ikisine de (indirgemeciliği ve bütüncülüğe de) kayitsız kalanlar.

Biz bu sınırlı incelememizde yelpazeyi geniş tutmayıp konumuz gereği Türk Akademiyasından en yakınımızdan hareketle birkaç örnek vermekle yetineceğiz. Öncelikle belirtmeliyiz ki Türk düşünür, aydın ve bilim adamları bu konuda (özne-insan ontolojisi) kendileri düşünerek en azından bir yorum bir açıklama getirmek yerine hazırı tüketmeyi tercih etmişlerdir. Oysa ontoloji bir şeyin açıklamasında tıpkı gömleğin ilk düğmesi gibidir. Yani ilk o kullanılmadan veya o atlanarak doğruca bir ilikleme veya düğmeleme yapılamaz. Zaten yapılanda sırasız, düzensiz ve yanlış olduğundan hemen dikkat çeker.

$\mathrm{Bu}$ dört maddeye karşılık gelen figürleri her akademisyen kendi merkezde olmak üzere üniversitesinde odasının bulunduğu koridorda, binada ve katıldığı ulusal-uluslararası 
sempozyum, kongre ve konferanslarda bulabilir. Nitekim bizde kendi koridorumuz ve katıldığımız ulusal-uluslararası sempozyum, kongre ve konferanslardan seçilmiş birkaç örnekle maddelere dair çok kısa tiplemeler yapacağız. Birazdan maddelere bazı örnek figürleri verdiğimizde görüleceği gibi özne-insan ontolojisi arayışında kahir ekseriyet yukarıdaki dört maddenin üçünün etkisinde kalıp gerçekte kendilerinin olmayan indirgemeci sermayeyi tüketseler de tek tük de olsa ircacı tehlikenin farkında olup ona karşı bütüncü yaklaşımla karşı çıkanlarda mevcuttur. Şimdi sırasıyla maddelere birkaç örnek vererek özne-insan ontolojisine dair Akademiyamızın durumunu görelim.

\section{Indirgemeciliği Tehlikeli Gören Bütüncüler}

Burada k1saca merhume Amiran Kurtkan Bilgiseven anti indirgemeci bütüncü yaklaşım ve uygulamasından söz etmek muhtevamız açısından doğru olacaktır. Sosyolog olup din sosyolojisinde özelleşen Bilgiseven'in hemen hemen bütün eserlerinde ircacılık karşıtı bütüncü özellik dikkat çeker. Özne-insan ontolojisi ve bu ontolojiyi oluşturan öğelerin analizine dair yazılan "Emanet" adlı eserinde düşüncelerini ortaya kor. Kitapta: "Emanet" (insana/homo sapiense verilen ilahi "ruh" emanetini); "iman" (ruhun muhteva, iş ve işleyişinin şuurunda olarak sahibine emanetçi bilinciyle inanıp güvenip dayanmasını); "dua" (bu ilahi bedenleşip canlanarak ruhlaşan öznelik adayı insanın Yaratıcısı ile zihinsel, ruhsal ve bedensel olarak halleşmesini); "akıl” (özne-insanın hayatının aktif, itici, kontrolcu nazari mekanizmasının biricik ve başat öğesi olmasından); ve "irade" (akıl yetisinin eylem alanında işlevselleştirimesinin olmazsa olmaz öğesinin özne-insanın iradesi olduğundan) kavram ve olgularının muhteva ve işlevlerinden hareketle özne-insan merkezli bir ontoloji inşa etmeye çalışır. (Bilgiseven, 2002)

$\mathrm{Bu}$ makalenin yazarını bir tarafa bırakacak olursak bizim bildiğimiz Türk Akademiyasında ilk ve orijinal tek çalışmadır. (“Özne-İnsan Ontolojisi”"nin Açıköz'ce kurgu ve sistematiğine dair bakınız Açıköz, 2006a; 2006b; 2019a; and 2004) Bilgisevenin bizim örneğimizde de olduğu gibi çıkış noktası ilkeler kitabı Kur'an ve ilimdir. Nitekim bu ontolojik zemin üzerine "Kur'an'dan Beş Hikmet" adlı eserini yazarak özne-insanın onto-epistemolojik, onto-etik ve onto-estetik değerlendirmesini yapmıştır. (Bilgiseven, 2001) Günümüz Akademiya mensupları özne-insan ontolojisine dair bu bütüncü bakış açısı ve uygulamasını daha ileriye taşımalıdır.

Nitekim Bilgisevenin talebesi F. Beylü Dikeçliğil bu gereği anlayıp kendi akademik çalışmalarında bu misyona dair bir farkındalık oluşturarak onu ileriye taşıma çabasında olmuştur. Bu cümleden olmak üzere Dikeçliğil "Ontolojiyi Hatırlamak: Sosyolojide Yöntem Sorunu” (2017) adlı eserini kaleme almıştır. Kitap genelde felsefede ve özellikle sosyal bilimlerde özne-insan ontolojisinin ircacı parçacı pozitivist anlayışa karşı olarak bütüncü inşasının acilen gereğini vurgulamaktadır. Bunun da nasıl olacağını genelde sosyal bilimler özelde sosyoloji örneklerinde: Önsöz; Giriş; Sosyolojide Metodolojik Farklılaşma ve Metotlar Arası İşbirliği; Bilimsel Paradigmaların Oluşumunda ve Dönüşümünde Sosyolojik Bağlam; Sosyal Bilimler Epistemolojisinde Sorunların Kaynağı: Ontolojiyi Unutmak; Kültür Kavramının Analizi veya Sosyo-Kültürel Gerçekliğin Yapısı Üzerine Bir İnceleme; Sosyal Yapı
Analizi ve Bir Analiz Model Denemesi: 'Sosyal Yapı' ve 'Toplumsal Yapı' bölümlerinde özgün bir şekilde anlatmaktadır.

Ayrıca Dikeçliğil (2017) "Sosyal Bilimlerde Ontolojik Öncül Olarak İnsan" adlı uzun araştırma makalesinde sosyal bilimler temelli bizim "özne-insan" ontolojisi inşasının aciliyetini bütüncü anlayış ve metodik yaklaşımı gereğince kendince orijinal tespitler yapıp değerlendirme ve önerilerde bulunmaktadır. Bilgiseven ve Dikeçliğil'in görüşlerine dair daha kapsamlı bilgilenme için Kaynakça'da belirtilen eserlerine bakmaları önerilir.

Öte yandan, yeni kuşak felsefecilerde özne-insan ontolojisi bilincinin oluşumu farkındalığına Muminoğlu'nu örnek verebiliriz. Muminoğlu (2016) "Sosyal Kalkınmada Sosyal Felsefenin Rolü" adlı makalesinde bu çerçevede şunları belirtmektedir: "Bu anlamda toplumumuzun yeniden kalkınma hamlesi, tıpkı Rönesans ile Batı medeniyeti nasıl yeniden kalkınma hamlesinde kültür köklerini, kaynağa dönüş fikriyle Roma -Yunan kültür ve medeniyetlerine dayandırarak gerçekleştirdiyse, sahip olduğumuz İslam değerleri ve prensipleri üzerine varolan yaşam felsefemizi yeniden kendi ruhunda canlandırmakla, kendi sistemimizi bütün disiplinlerde yeniden oluşturabiliriz. Nitekim bütün İslam ülkelerinin tek ihtiyacı bu, kendi İslami değerleri ve prensipleri üzerine insan, toplum, ekonomi ve devletin bütün disiplinlerinde gerekli sistemleri inşa etmektir. Türkiye buna örnek olacak potansiyeldedir." (Muminoğlu, 2016; UNIDAP: 543 (534-544)

\section{3. İndirgemeciliği Tehlikeli Görmeyen İndirgemeciler}

Günümüz Türk Akademiyasında maalesef kahir ekseriyet ircacılğın etkisi altında olup adeta güçleri el verdiğince gönüllü temsilciliğini yapmaktadırlar. Yine bizi yakın çevremizdeki şahitliklerden hareketle bu başlık altında pek çok örnek vermek mümkünken biz bizimle ilgili sadece Baran örneğini vermekle yetineceğiz. Ulusal bir kongrede homo Muslimus eksenli özne-insan ontolojisi takdimini içeren bildiri muhtevasına özellikle homo Muslimus nitelemesine dair pozitivist indirgemeci sı̆ alışkanlıkla kongre değerlendirilmesi oturumunda içtenlikle şunları söylemektedir.

“... O yüzden bir taraftan bunlar konuşuluyor, arkasından bir hocamız homo Muslimus hakkında konuşuyor. Ben anlayamadım yorgunluktan. Bilmiyorum yani o kavramı, homo Muslimus: bu çok enteresan geldi gerçekten. Hem biz niye her insanı Müslüman yapmak zorunda oluyoruz ki yani. Herkes istediği dine inansın, herkes istediği şekilde yaşamaya çalışsın, yaşam tarzını uygulamaya çalışsın. Biz burada bir şeyi kaçırıyoruz galiba: İnsanı, insanı. İnsana verilen değeri kaçırıyoruz. Yani, bizde bir baba figürü var... dolayısıyla çok fazla sözü uzatmadan benim bu şoka uğradığım iki konuyu, bu kongre bana bunları kazandırdı. Ben hala üzerinde düşünüyorum. Bu plansız yaşamak nasıl olacak? İkincisi homo Muslimus nasıl bir konudur? Bunları düşünüyorum... A. Fethi POLAT ... Bu homo Muslimus konusuyla ilgili çokta konuşulduğu için bizim şunu görmemiz gerekir. Bir araya gelmemiz için büyük darbe yememize gerek yok..." (UNIDAP, 2016: Cilt 2; ss. 608610) 
Öte yandan, birakalım alternatif bir "özne-insan ontolojisi" ortaya koymayı bu duyarlılık seviyesinde olan Baran'ın merakını gidermesi için en azından bildiri sahibine ulaşıp bildiri konusu hakkında fikir alışverişinde bulunması gerekir. Maalesef ircacılık böyle bir bütüncül misyonu yüklenmeye doğası gereği engeldir. $\mathrm{Bu}$ nedenle ircacılar/indirgemeciler böyle bir denemeye girişemezler. Giriştiklerinde de sonuç eksik, kadük, yıkıcı ve yanlış olur. Çünkü unutmamalıdır ki: "Yarım doktor candan, yarım imam imandan eder". Bu tür örneklemlere ulusal ve uluslararası seviyelerde sıkça rastladığımız için bu maddenin açılımını Baran ile burada sonlandırmamızın doğru olacağı kanaatindeyim.

\section{4. İndirgemecilik ve Bütüncülük Arasında Kalan Aradakiler}

Anlama ve bilgi arayışlarında özne-insan ontolojisine dair düşünsel ve ameli yaklaşımlarda mevcut verilerden hareketle "özne arkeolojisi" nitelemeli bir denemeye girișen Tüzer (2016) “Postmodernizm ve Tanrı'nın Ölümü: Öznenin Arkeolojisi Üzerine Bir Deneme" adlı kapsamlı, derinlikli ve ince işçilikli araştırma makalesinde ilginç ve bazı orijinal tespitlere ulaşmış olup "şimdiye kadar elin işini yaparak ele çalıştık şimdi ise kendi işimizi kurarak kendimize çalışma zamanı" deme eşiğindedir. Nitekim, "modernizm ve Tanrının tahtına oturan özne; Tanrının ölümü öznenin de ölümü demektir" tespitlerinden sonra "dinin sonu mu?" diye sorup "Tanrıyı öldüren insan gerçekte kendini öldürmekte" olduğu tespitiyle soruya cevap vermektedir. Tüzer cevabını da malzeme yoğunluğu düşünsel teknik ince işçilikle temellendirmeye çalışmaktadır. Fakat çok yoğun bir özne kazısı (özne arkeologluğu) yapisına rağmen ortada bütünü temsil eden özne-insan yoktur. Çünkü yoğun malzemede bolluğu, parçada ve kazı sürecinde kaybolmuştur.

Zira Tüzer, malzemelere son derece hakim olup onları el menüsünde kullanmaktadır. Oysa çok rahat bir şekilde kendi mutfağının aşçılığını yaparak hem batı hem de doğu mutfaklarında gurmeleşebilir. Buna engel ise, felsefe ve bilim eğitim ve öğretiminde indirgemeci baskın etkinin doğal sonucu olarak öğeler detaylı bıktırırcasına uzmanlık adına analiz edilirken öğelerin bünyesinde yer aldığı bütün kompozisyonun ortada olmamasıdır. Çünkü parça veya öğe mensubu olduğu bütünde kimliklenip anlam kazanır. Aksi durum bütün insan vucudu anatomisini sadece kulağa veya kalbe indirgeme saçmalığına benzer. Sonuçta özne-insanın onto-kozmolojik yerine, statüsüne, yapısına, önem ve işlevine baktığımızda; evet, tanrıdan adeta rol çalan ve tanrıyı öldüren insan gerçekte kendini öldürmekte; ve homo skeptikusluk donanımını kullanarak 0 noktası anima homolusluktan homo animalusluğa kendi özgür bilinç ve iradeleri ile evrilmektedirler.

Diğer bir çarpıcı örnek ise, "kanaatin veren eli (İslam insan1) ile kapitalin homo economicus'u arasında yaşanan duygusal salınımlar" adlı bildiri sahibi Bilgin'dir. Bildiri konusu eksenli özne tanımında bulunup teo-etik boyutlu tartışan Bilgin şunları söylemektedir: “... Günümüzün biz çağdaş Müslümanları, tarihsel tecrübe ve pratikleriyle örtüşmeyecek şekilde; hal, hareket, tavır, eylem; düşünce, duygu, yaklaşım, eşyaya, tabiata ve olaylara bakışaçısı vb. konularda birer İslam insanı miyız yoksa homo economicus mu? (başka bir deyişle) günümüzün biz Müslümanları,
İslam insanına $\mathrm{m} 1$ yoksa homo economicus'a $\mathrm{m} ı$ daha yakınız yahut bunlardan hangisine daha çok benzemekteyiz?" (Bilgin, UNIDAP, 2016: s.382 (370-383)

Bilgin, çalışmanın başından beri İslam insanı ile iktisadi insana dair özellikler zikretmekte, çeşitli karşılaştırma ve değerlendirmelerde bulunmakta, ve netice de İslam insanının pozitif özelliklerinden dolayı kapitalist dünya iş ve işleyişinden dolayı hem teoride hem de nazariyede kusurlu tipoloji olarak değerlendirildiğini ifade etmektedir. Oysa özde özne-insanın değişik parça türevlerinden olan İslam insanı ve iktisat insanı çok yüzlü özne-insanın iki yüzünden biridir. Eğer bilinçli veya bilinçsiz ircacı bir saikle parça bütünde değerlendirilmezse sonuç bütünsel kompozisyonu kaçırmak olur. Bize özne-insan homo skeptikus olan homo Muslimus'dur, gayrisi ise homo Muslimus'un (homo animalus, homo spiritus gibi) değişik türevleridir.

\section{Her İkisine de (İndirgemeciliği ve Bütüncülüğe de) Kayıtsız Kalanlar}

Bu şıkkı oluşturan, indirgemeciliği ve bütüncülüğe kayıtsız kalan, akademisyenleri ulusal ve uluslar arası seviyelerde kahir ekseriyetle her akademik ortamda sıkça rastlamak mümkündür. Buna rağmen biz yakın çevremizden olan Alican'ın (2020) tavrını kısa bir örnek olarak vereceğiz. Alican çok zeki, çok yönlü ve çok üretken tarihçi bir akademisyen olmasına rağmen özne-insan ontolojisi tartışması merkezli indirgemecilik ve bütüncülük karşıtlığında arada kalmaktan kendini kurtaramamıştır. Alican youtube konuşmalarından olan "Antikiteden Postmoderne Özne ve Tarihçilik", (Mayıs 2020), adlı konuşmasında "modernitenin karakteristiği mutlaklık, post modernitenin karakteristiği muğlaklık" gibi original tespitler yapıp bütün parçalarını birbir ortaya koyarken maalesef ircacı narkozun etkisiyle bütünü parçada yok etmektedir. Adeta bütünü kendisini oluşturan parçalarına/öğelerine meze etmektedir. Her ne kadar özneinsan ontolojisinde tarihi perspektifte nakıslık ve ruhsuzluk ihtivalı bir problem olduğuna dair farkındalığı olsa da ircacılığın etkisi altında kalarak çözüme gidememektedir.

Oysa diji/postpost modernitenin karakteristiğinide belirttikten sonra Alican'dan beklenen bütün dönemlerin temelinde olan "özne-insan”a dair tarihi çerçevede ontolojik bir teori veya açıklama yapmasıdır. Lakin ircacılıkta veya ircacılığın tarihsel etkisinde gelinen noktayı bizce diji/postpost modernitenin karakteristiği en çarpıcı bir şekilde göstermektedir.

Nitekim diji/postpost modernitenin karakteristiği şunlar: kerhencilik, merdi kıptilik, tinercilik, anlamsızlık meczubiyeti, serseri esrikliği, nankörlüğün ve hayvani köke ircacılığın en noktası, anlık her türlü heva ve hevesin tatminin tabulaşması ve kutsanması, ve çağdaş sefihlerin sefihliği oluşturmaktadır. Bu karakteristiğin bizce eylem tarzının ifadesi ise: "Konjonktürel anlık göreceli ilkesiz hayvani mış gibiciliktir veya yaşıyor gibi yapmaktır.

Akademisyenlerimiz verileri örneklerinde özne-insan ontolojisi merkezli ircacılığa ilişkin tavırlarını çok genel görüp Akademiyamız hakkında sınırlı da olsa bir fikir edindikten sonra şimdi bu zemin üzerine bizim kendimizin konuya dair açıklama ve yorumumuza geçebiliriz. "Özneinsan ontolojisi”" bileşke ifadesini oluşturan "öznelik” veya 
“özne-insanlık” tanımı gereği bir eylem hali veya durumu olup insan türünden bir özneye/eyleyene ilişkindir. Yani, öznelik bir öznenin/eyleyenin eylemidir. $\mathrm{Bu}$ eylemde insanca bir eylemdir. Çünkü insan dışındaki diğer varlıklar eylemezler ama harekette, edimde ve davranışlarda bulunabilirler. Malum insanın ayrıcalığı akıl, irade ve vicdan sahibi bir varlık olmasıdır. Rescher'in (1970) sorulara koşut oluşturulan eylem analiz tablosuna müracaat ederek bizim “öznelik" veya "özne-insanlık” eyleminin anatomisini ortaya koyan öğeleri sirasıyla şöylece sunabiliriz.

\section{Eyleyen: Kim (eylemi) ortaya koydu?}

- “Özne-insan” veya “Özne-insan”a “Özne-insan”l1k yükleyen üst-insan

\section{Eylemin Türü: Ne eyledi veya eylendi?}

- İnsanca öznelik eylemi yapıldı

\section{Eylemin Modu: (Eylem) nasıl yapıldı?}

a. Nasıllık modu: (Ne halde eylem yapıldı?)

- İnsanca aktif öznelik eylemi yapıldı

b. Vasita modu: (Ne vasitayla eylem yapıldı?)

- Akıl ve irade vasitasıyla insanca aktif öznelik eylemi yapild 1

\section{Eylemin Çerçevesi: (Hangi çerçevede eylem yapıldı?)}

a. Zaman: (Ne zaman eylem yapıldı?)

- Genel insanlık tarihi yanı sira bireysel tarihlerinde insanlar insanca öznelik eylemi yaptı.

b. Mekan: (Nerede eylem yapıldı?)

- Genel insanlık tarih sahnesi olan yeryüzünün yanı sıra bireysel tarihlerin sergilendiği lokalitelerde insanlar insanca öznelik eylemi yapt1.

c. Ortam: (Hangi şartlar altında eylem yapıldı?)

- Zihinsel ve ruhsal haleti ruhiyeleri ve buna koşut oluşan dünyagörüşleri çerçevelerinde belli zaman ve lokalitelerde insanlar insanca öznelik eylemi yaptı.

\section{Eylemin Rasyonel Boyutu: (Niçin eylem yapıldı?)}

a. Nedensellik: (Neye sebep eylem yapıldı?)

- Ontolojik yapıları ve insanlık üst yapı donanımları (ruh=akıl+irade+vicdan) gereğiyle/nedeniyle insanca öznelik eylemi yaptı.

\section{b. Amaçsallık: (Ne amaçla eylem yapıldı?)}

- Evvelen kendini bilerek evreni bilmek; kendini ve evreni bilerek bütün mevcudatın yaratıcı gücü, iş ve işleyişlerinin teminatı olan aşkın gücü (Tanrıyı) bilmek, anlamak ve anlamlandırmak amacıyla insanca öznelik eylemi yaptı.

c. Niyet: (Hangi motivasyonla eylem ortaya kondu?)

- Kendisi de dahil olmak üzere varlığı ve varoluşu bilmek, anlamak ve anlamlandırmak niyetiyle insanca öznelik eylemi yaptı.

Diğer taraftan bizim "öznelik" veya "özne-insancılık" eylemine dair yukarda sunulan uyarlamamız dikkate alındığında bu soruları değişik yaklaşımlardan hareketle bir dizi teoriler ileri sürülerek çeşitli cevaplar verilebilir. $\mathrm{Bu}$ yaklaşım ve teoriler şu iki ölçütten yola çıkarak iki ana grupta toplanabilir: 1. Özel (indirgemeci ve holist) yaklaşımlara paralel öne sürülen teoriler; ve 2. "Kim eylemi ortaya kor?" veya "İnsan eylemlerinin ortaya çıkmasına ne veya neler sebep olur?" sorularını esas alarak 'olaykozalite' veya 'eyleyen-kozalite' anlayışlarından hareketle ortaya atılan teorilerdir. (Pols, 1979)

$\mathrm{Bu}$ iki farklı kozal anlayış günlük hayatta eylemlerimizi sergilerken zaman zaman başvurduğumuz şu üç sağduyu tecrübesiyle açıklanabilir. Bunlar: a) "nedensellik ilkesi", ve b) "ön tartım" ve 111) "o (nu yapmak veya yapmamak hakkı) benim keyfiyetim (dahilindedir)" deyişinde anlamını bulan açıklamadır. Birazdan teorilerin açıklamasında göreceğimiz üzere "öznelik" veya "özne-insanlık" eylemi tarihsel süreçte hep bu iki eksene oturtularak gerçekleştirilip açıklanmıştır. (Bishop, 1989) Yani "olaykozalite" eksenli indirgemeci anlayış ve uygulamada "öznelik" veya "özne-insanlık" eylemi eylemcisi gibi kör eylemdir. (Goetz, 1989) Oysa "eyleyen-kozalite" eksenli tümcü/bütüncü anlayış ve uygulamada "öznelik" veya "özne-insanlık" eylemi aktif bir eyleyenin veya öznenin eylemi olup rasyonel ve amaçsal bir eylemdir. (Glover, 1991)

J. Shaffer (1968) insan eylemine ilişkin teorileri şöylece sıralar: Yönelimsel; aktif eyleyenlik; performatif; amaçsal; ve çerçevesel eylem teorileridir. Bu teorilerin ana ilkesini bizim "öznelik" veya "özne-insanlık" eylemimize özce şöylece uyarlayabiliriz.

1. Yönelimsel eylem teorisi: “Öznelik" veya “özneinsanlık" eyleminin özel statüdeki zihinsel durumlar ve olaylar tarafından sebeplendirildiği iddiasında bulunur.

2. Aktif eyleyenlik teorisi: "Öznelik" veya "özne-insanlık" eyleminin sebebi olay değil, aksine eylemi gerçekleştirenin bizatihi kendisidir. Ben eylemde bulunduğum zaman, eylemi gerçekleştiren ben kendimim bir başkası değil. Doğal olarak eylemin sebebi ve faili ben kendimim.

3. Performatif teori: "Öznelik" veya "özne-insanlık" eyleminin yönelimsel eylem olarak ifade edilmesi şeylerin nasıl olduğunu veya neyin neyi sebeplendirdiğinin bir tanımlanması veya raporu değildir. Harekette bulunan eyleyene sorumluluk yükleyen eylemim yapım tarzı ve yapılışıdır.

4. Amaçsal teori: "Öznelik" veya "özne-insanlık” eyleminin eylem öncesi durum, olay veya aktif eyleyenle açıklanmasından ziyade, gerçekte hareketin amacı ile ancak açıklanabileceğini savunur.

5. Çerçevesel eylem teorisi: "Öznelik" veya "özne-insanlık" eylemi yönelimseldir, şayet o kurallar, normlar veya genel uygulamalar çerçevesinde anlaşılıp, anlatılmışsa. (Shaffer, 1966: 80-81)

Özne-insanın anlam ve bilgi arayışlarında öznelik ve özneinsanllık eylemsel çerçevesinin öğelerini ve bu çerçeveye getirilen yaklaşım ve teorileri gördükten sonra şimdi özneinsanı felsefi genel düzleme nasıl bir yer tutacağına bir bakalım. Özne-insanın ontolojik/varlık statüsünü belirleyecek temel ontolojik iki soru şudur. Gerçekten "özne-insan" diye bir varlık var mıdır? Şayet varsa ne türden nasıl bir varlıktır? Evet gerçekten ete kemiğe bürünmüş şekilde üst yapılı gözlem alanına çekip 
inceleyebileceğimiz bir varlık vardır. Bizim "özne-insan" bileşke ifademiz durumunda "özne" kelimesi insanı nitelemektedir. Yani nesnel/material türden gerçek bir varlığa sahip olan insan özne olma niteliğini/sıfatını bünyesinde barındırmaktadır. Aynı iki soruyu "özne" kavramına da yöneltebiliriz. "Özne" kavramının bizatihi ontolojik konumu bakımından maddi bir türden varlığ olmasa da ona karşılık gelen ideal türden bir varlığı ve işlevi mevcuttur. Bu durumda "özne-insan" denilince akla özne konumundaki insan gelir. $\mathrm{Bu}$ statüler ontoepistemolojik zemine içerik ve işlevlerine dair sorularla ancak çekilebilir.

Evreni, insanı ve Tanrıyı anlamlandırma çabasının dinamik entelektüel ifadesi demek olan bilgi faaliyetindeki kullanılan bütün kavramların en azından dört statüsü vardır ki bunlar birbirleri ile doğrudan ilintilidirler. Genelde bu ilintiyi nazari seviyede kurma maharetini felsefeye yani filozoflara/felsefecilere verilir. Hatta bunlar malum olduğu gibi felsefenin temel disiplinleri olarak bilinir. İşte bu yüzden kanaatimce filozof/felsefeci o dur ki, kendisine verilen herhangi bir kavramı birbirleri ile doğrudan ilintili olarak bu dört alanda işlevselleştirip ifade edebilir. Felsefenin olumlu anlamda kavram ve söz cambazı olması işte bu anlamda anlaşılmalıdır. Oysa günümüz çoğu felsefecisinde bu yeti, anlayış ve uygulama maalesef yoktur. Çünkü bir kavramın veya kavramsallaştırılmış bir olgunun epistemolojik zeminde sorgulanmasının/incelenmesinin yapılabilinmesi için öncelikle onun ontolojik yapı ve işlevinin bilinmesi gerekir ki epistemolojik sorgu zeminine böylece taşınabilsin. Sonra epistemolojik zemindeki incelemeden sonra a kavramın etik ve estetik statülerinin analiz ve değerlendirilmesine geçilebilir.

Eğer bir kavramın bütüncül bir içeriksel işlevinin incelenmesinin yapılması isteniyorsa sadece felsefe alanında değil diğer bilgi ve bilim alanlarında da kavram bu aşamalardan geçirilmek zorundadır. İşte bu yüzden ontolojik bir öncül olarak "insan”'ın (yani, “özne-insan”ın) yeniden inşasına gerek vardır. $\mathrm{Bu}$ inşa sadece Yunandışı düşünce ve bilim çevreleri için değil aynı zamanda materyalist ircacı Yunancı düşünce ve bilim çevreleri içinde bir gerekliliktir. Çünkü beyaz Avrupalının uygarlığı topal ördek olup indirgemeci anlayış ve uygulamaları gereği eksik, sakat ve tek taraflidir. O bir beden ve madde uygarlığıdır. Bu gerçeğe rağmen kendini rasyonel zeminde inşa ettiği için nakıslığına rağmen diğer düşünce çevrelerini etkileyip güdebilmektedir.

Oysa diğerleri ise kopyayı ve taklidi bile gereği gibi beceremeyip ekmek elden su gölden misali el erkiyle gerdeğe girip düşünce ve bilim adına düğün dernek yaparak yamalı bohça olmalarına rağmen kendilerini özgün ve özgür sanıp sözde kendilik söylemlerinde bulunabilmektedirler. Adeta merdi Kiptice söylem ve eylemlerde bulunarak figüran olarak yer aldıkları düşünce ve bilim podyumlarında kendilerince avare kasnak misali moda gösterileri yapmaktadırlar. Böylece akademisyencilik, bilimcilik ve felsefecilik oyunu oynamaktadırlar. Yani, kendileri çalıp, kendileri söyleyip yine kendileri oynamaktadırlar. Maalesef çoğu durumlarda akademin ekmek kapısı olmaktan öteye geçememektedir.

Anlam ve bilgi arayıcısı olan bilen özne insanın varlıkbilgi-değer üçlüsüne dair felsefi spekülasyonlar yaparken kendini varlığın bir parçası olarak bilgi konusu etmesi, yani, kendi üzerine düşünmesi onu varlıkların bilgi arayışı düzleminde farklı ve ayrıcalıklı bir konuma oturtur. Zaten malum inşa evrendeki bütün canlı-cansız varlıklar içinde bu özellik, özgürlük ve statüye sahip tek varlık olarak bilinir. Ayrıca aklı maharetiyle spekülasyon yaparken aynı zamanda manipülasyon yapabilen tek varlıktır. Yani, istediğinde beyazı siyah veya siyahı beyaz yapan; doğruyu yanlış veya yanlışı doğru yapan; iyiyi kötü veya kötüyü iyi yapıp diğerlerini bilinçli yanıltabilen tek varlıktır.

İnsanın bilgi eksenli her yönüyle içsel ve dışsal bütüncül bir portresinin çizilmesi veya fotoğrafinın çekilmesinde ontolojik temel çıkış postüla veya ilk aksiyomatik ilke insanın et-kemikten ibaret organik bir varlık olduğu tezini içeriyorsa daha başlangıçtan insanın epistemolojik topoğrafyası, biyo-psiko-zihinsel kimyası ve kompozisyonu belli demektir. Yani, bütün zihinsel ve ruhsal süreçleri fizyolojiye indirgeyip o merkezde takdim edip değerlendireceklerdir. Bizim kendi terminolojik ifademizle şüphe/merak eden (homo skeptikus'u) özne-insanı iki indirgemecilikten birine savrularak ya hayvansı insan (homo animalus) ya da ruh insan/insan-1 ruh (homo spiritus) olarak takdim edilecektir.

Epistemolojik zeminde sosyal bilimlerde ontolojik öncül olarak insanın değerlendirilmesi dikkate alındığında bu indirgemeci tek taraflı özelliğin özgür, özgünce ve savrukça gerçekleştirdikleri görülür. Anlam ve bilgi arayıcısı olan homo skeptikus'u “özne-insan"'ın epistemolojik zeminde iki indirgemecilikten; hayvansı insanlıktan (homo animalusluktan) veya ruh insan/insan-1 ruh (homo spiritus) birine savrulmasının doğal etiksel sonuçları olacaktır. Başka bir ifadeyle, anlam ve bilgi arayışında "özne-insan"a dair bu tür onto-epistemolojik düşünsel kisve biçip dikmeye koşut yapılacak bir etiksel elbise takdim ve değerlendirme ana temel önermenin veya ilkenin doğal etkisini taşıyacaktır. Yani Hume'un ifade ettiği gibi, aklı tutkuların kölesi/hizmetçisi ilan ederek özgürlük veya özgür-özgün iradeyi motivasyonlar/dürtülerin etkisine terk edecektir. Hayatta bu çerçevede kayıtsızca "mış gibi" yaşanacaktır. Zihin ne idüğü belirsiz bir dizi idealar topluğundan başka bir şey değildir. Bunun bilimsel kisve ile ideolojik dişa vurumu (bilimsel) sosyal Darwinizm, (bilimsel) nasyonalizm, (bilimsel) kapitalizm ve (bilimsel) komunizmdir. $\mathrm{Bu}$ ikil indirgemecilik de bütünü parçaya indirgeyerek bilgi faaliyetin yumuşak karnı olup çok ciddi zararlar vermiştir.

Anlam arayışı yolculuğunda bilim ve felsefe yapan özneleri gibi üzerine çalıştıkları çalışma konusu olan "özne-insan"a da aynı ideolojik anlayışla yaklaşıp materyalist, pozitivist zeminde açıklama yapmaktadırlar. Her türlü zihinsel ve ruhsal edimlerini fizyolojisine indirgeyip sadece et-kemik yığını biyolojik bir organlar topluluğu kesilip biçilen varlık olarak görmektedirler. İnsan uygarlıkları genelde insanın nazari ve ameli eserlerinin sergilendiği canlı aynalardır. $\mathrm{Bu}$ nedenle medeniyet aynasındaki insana dair her türlü görüntü gerçekte hikayesi anlatılan aktif ana aktör "özneinsan"ın estetik içerik, önem ve işlevinin ameli durumunun göstergeleridir. $\mathrm{Bu}$ göstergeler bize “özne-insan”in ontolojik konumlandırılması; kendisine dair anlatılan ontoepistemik ve onto-etik hikayeye koşut beden (madde) uygarlığı estetiği, ruh (mana) uygarlığı estetiği ve (madde+mana) karma uygarlık estetiği olarak üç türlü 
uygarlık estetiğini verir. Gerçekte anlam ve bilgi arayışlarında aktif özne-insanın ontolojik, epistemolojik, etik ve estetik konuşlandırılması müstakilen ele alınıp detaylı bir şekilde değerlendirilebilir.

\section{Sonuç}

Genelde bilgi ve anlam arayışı tarihsel faaliyetinde özelde şimdiye kadar söz konusu ettiğimiz bütün bu tespitlerin merkezindeki “aktif özne"nin (“özne-insan”ın) içerik ve işlevini ontolojik, epistemolojik, etik, estetik alanlarda ve bu alanların birbirleri ile olan doğal etkisel birlikteliği bakımlarından durum ve statüsünü bu baskın güç çevreleri belirlemektedirler. İnsanın akıl hamaliyeliği tarihi bize göstermektedir ki, hangi alanda olursa olsun bilgi ve anlam arayış faaliyetinin özne ve nesnesinin kimliğine, neliğine, niçinliğine ve nasıllığına onlar karar vermektedirler. Dolayısıyla özne de ve öznenin uğraştığı nesneler veya uğraş konuları da onların olmaktadır.

Nitekim düşünce ve bilim tarihlerinde özellikle felsefe de çeşitli filozoflar tarafindan daha çok nazari çerçevede değerlendirilmeler yapılmıştır. Ancak bizim inceleme amacımız özne-insanın ontolojisi ve bu ontolojiye dair günümüz akademik farklı yaklaşımlar ile sınırlı olduğu için bu kadar değinip geçeceğiz. Baskın olduğu toplumlarda ise, zaman zaman değişik yazılarımızda bağlamına göre gönderme yaptığımız, Merza Fakur Heliki'nin dediği şu tespit gerçekleşir:

"Bir ülkede evvelen ulema ve umera; saniyen mef'umlar ve müesseseler ifsad olur; bu mecraya salisen esnafin vicdan terazisinin ifsad ve iflası da ilave olunduğunda (biline ki orada ifsadoloji (imajoloji), mufsid (imajist) ve alg1 operasyonu (manüpülasyon) mesaidedir, artık maneviyat, milliyet ve medeniyet yok; heva heves, meczubiyet, yalan ve ahlaksızlar ahlakı vardır); bundan gayri eğer takadınız varsa o ülkenin her türlü çöküşünü seyir eyleyiniz." (Merza Fakur Heliki, 1424)

Akademiyadaki "özne-insan" merkezli anlam ve bilgi arayışlarında hem nazariye hem de amaliyede bu tehlikeli duruma düşmekten ancak sonuçsal tespit ve önerilerimizi içeren aşağıdaki verilen mantıksal sebep-sonuç örgülü maddelerin aksini yapmakla kurtulabiliriz.

1) İnsanın “özne-insan” olarak çizilen ontolojik resminin bilinçli olarak indirgemeci saik ile yapılması.

2) Bu saikin bilimsellik yaftası veya pateni ile bir ideolojiye hatta doktrine dönüşmesi.

3) İnsanın bütünsel ontolojik yapının parçaya indirgenmesi, böylece parçada bütünü değerlendirerek bütünün içini boşaltarak böylece "özne-insan”’ın içini boşaltmak.

4) $\mathrm{Bu}$ indirgemeci saik ve uygulamanın kurumsallaşıp galatı meşhur durumuna gelmesi.

5) Doğrunun konjonktürel veya durumsal kılınıp kamplara, hiziplere ve lobilere ayrılmasi; yani bir doğrudan değil bin doğrudan söz edilir duruma düşülmesi.

6) Eksikliğin (nakıslığın) benimsenip yerine göre bütüne şamil kılınması ki bunun bir ileri adımı doğrunun yanlışa; yanlışın doğruya karşılık getirilmesi demektir.
7) Sonuç özdeşlik ilkesinin deforme edilip ortama, zemine ve zamana göre $\mathrm{A}=\mathrm{A}$ dır önermesinin $\mathrm{A}=\mathrm{B}$ 'ye; $\mathrm{A}=\mathrm{C}$ 'ye ... $\mathrm{A}=\mathrm{Z}$ 'ye evrilerek kaosa kapı aralamasıdır.

Diğer taraftan bu maddelerin uygulayıcı bireysel ve kolektif özne-insanları demek olan Akademiye mensuplarına yansılarını ise genel olarak maddeler halinde şöylece siralayabiliriz:

1) Çoğu Akademiya mensupları arasında aidiyet, sahiplenme ve temsil duygusunun yok veya zayıf olmasi.

2) Özgün ve özgür anlayış ve ruhun olmayışından kaynaklanan kimliksizlik, özgüvensizlik ve aşağılık kompleksine sahip olup karşıtına aşık olup methiye dizmek, eli erleştirmek eri elleştirmek.

3) $\mathrm{Bu}$ olumsuzlukların başta Akademiye olmak üzere diğer kurumlara yansımaları sonucu mış gibi yapmak, görüntüyü kurtarmanın esas alındığı ekmek kapısı olan istihdam yerlerine dönüşmesi.

4) Aile kurumuna yansısı çocuklarına dükkan açtıracak, mevki, makam, şan ve şöhret sağlayacak maddi hiçbir sıkıntı duymayacağı üç nesli de madden garantiye alacak bir eğitim ve meslek seçimi kolaycılığına itmek.

5) İdareye veya siyasete yansısı günü ve görüntüyü kurtarmak için laf ebeliği sofistlik yapmak.

6) Hazırcı anlayış ve uygulama ile taklit ve tekrarcı olup gönüllü fahri taşeron, bayii ve temsilci olmaları.

7) yerli ve milli olmamaları aksine dünya vatandaşı olduklarını iddia edip onun da gereğini yerine getirmemeleri.

8) Özendikleri toplumların meslektaşları akademisyenlerinde bu yapay ve uyduruk 10 . ve 11 . dereceden kopyalarına prim vermemeleri.

9) İlkesiz, dipsiz, omurgasiz, düzlemsiz, irrasyonel, kişiliksiz, şarlatan, etiksiz ve pragmatist olmaları vb.

Sonuçta maalesef felsefeci ve sosyal bilimci Akademisyenlerin çoğunluğu asli görevleri olan tarihe anlam ve yön verip medeniyetler oluşturan "özne-insan"a dair kendi şahitliklerinde bütüncü ve kapsamlı bir teori bir sistem hatta bir açılama veya bir yorum getirmeleri bir yana kendileri mesleklerinin gerçek özne-insanları olamamaktadırlar. Bu nedenle bu bazı çoğunluktan nasıl başkalarına bir özne model olarak himmet edebilmeleri beklenir! Ama tam burada imdada Allah'tan popüler kültür ve alleme "sanal özne google" hazretleri yetişip şimdilik onların açığını kapatmaktadır. Eee! Ne demiş atalar nur için de yatalar: "Dağına göre kar" veya "Ne istiyon bacindan bacın ölüyo acından!"

Öte yandan unutmayalım aynı halk bilgeliği şunu da söylüyor: "Çıkmayan candan ümit kesilmez" veya "her dert devaya bir çağrıdır”. Öyleyse akademisyenler olarak hep beraber el, kafa, ruh ve ter birliğiyle bu kısır döngüden kurtulup özne-insanlığı önce kendimizde yaşatıp sonra tarihteki yolculuğuna uzanıp ona içerik, rol, işlev ve önem biçeceğiz. Böylece yarının akademisyen “özne-insan”ları kendilerini ircacı ruhsuz cazibeye kaptırmayıp genel tarihin “özne-insan”ına kendiyle barışık bir şekilde bütünde bakıp onu beden + can + ruh (=ak1l+irade+vicdan $)$ ontolojik terkipde değerlendirip kucaklayabilsin. 


\section{Kaynakça}

Açıköz, H. M. (2019c). “Antik Yunan Felsefesi ve Mitinin Kökenine, İçeriğine ve İşlevine Dair Homo Skeptikus'un Akıl Hamaliyeliği Tarihi Bakımından Felsefi Bir Kritik". Anemon. Journal of Social Science of Muş Alparslan University. 7 (6) 9-27.

Açıköz, H. M. (2003a). “Once Upon A Time There Was A Being Called Human", Lo Straniero 38, The Journal of IMISE, pp; 43-45. Naples, Italy.

Açıköz, H. M. (2003b). "Cumhuriyetimizin 80. Yılında Üniversite Örneğinde Eğitim Cephesi”, ss; 19-30, Polis Dergisi, 80. Yı1 Özel Sayısı (Sayı 35).

Açıköz, H. M. (2019b). "Toplumların İnşasında Batı Transhümanizminin İletişim ve Manüpülasyon Aracı Olarak Felsefe ve Eğitiminin Kullanımı", İletişim ve Medya Sosyolojisi Yazıları, Editor: Ü. Erkan, ss: 89132, Gece Kitaplı̆̆

Açıköz, H. M. (2019a). "Homo Muslimus Yazıları", Elis 141, Ankara.

Açıköz, H. M. (2017). "Sağduyu Eylem Felsefesi", 2. Bask1, Elis 101, Ankara.

Açıköz, H. M. (2006a). Homo Skeptikus ve Akıl Hamaliyeliği Tarihi Serisi 1. Kitap: "Skeptikus, Şüphe ve Bilgi ", Elis 34, Ankara.

Açıköz, H. M. (2006b). Homo Skeptikus ve Akıl Hamaliyeliği Tarihi Serisi 2. Kitap: "Tevhidi Kozmik Holizm, Şüphe ve Eski Uygarlıklar", Elis 37, Ankara.

Açıköz, H. M. (2004). "Bilgelik", Felsefe Ansiklopedisi, Editor A. Cevizci, Etik yayınları, Istanbul. Cilt 2, ss. $377-381$.

Alican, M. "Antikiteden Postmoderne Özne ve Tarihçilik”, Mayıs 2020, Youtube.

Ahmad, Israr (2016). “21. Asırda İslam Rönesansı”, Çeviren H. M. Açıköz, Araştırma 132, Ankara.

Ayer, A. J. (1969). "Man as a Subject for Science", London, 1964. "Metaphysics and Common Sense", London.

Baran, A. G. Kongre Değerlendirilmesi. Cilt II. Ss: 608610.

Bilgin, A. (2017). Kanaatin Veren Eli (İslam İnsanı) ile Kapitalin Homo Economicus'u Arasında Yaşanan Duygusal Salınımlar, Anemon Muş Alparslan Üniversitesi Sosyal Bilimler Dergisi. 5(2), 370-383.

Bilgiseven, A. K. (2001). Kur'andan Beş Hikmet. Filiz Kitabevi, İstanbul.

Bilgiseven, A. K. (2002). Emanet. Filiz Kitabevi, İstanbul.

Bishop, J. (1989). “Agent-causation”, Mind, vol. xcii, 1983. "Natural Agency", Cambridge.

Brand, M. (1970) “The Nature of Human Action”, USA.

Dikeçligil, F. B. (2017). Ontolojiyi Hatırlamak: Sosyolojide Yöntem Sorunu. Çizgi Kitabevi Yayınları. İstanbul.
Dikeçligil, F. B. (2017). Sosyal Bilimlerde Ontolojik Öncül Olarak İnsan. Ss: 145-188. Makale. Maneviyat Psikolojisi. Editor: M. Atak. Türdav. İstanbul.

Goetz, S. C. (1989). “A Noncausal Theory of Agency”, in Philosophical and Phenomenological Research, vol.49, 1988/9.

Glover, J. (1991). "I: The Philosophy and Psychology of Personal Identity", reprinted in Penguin Books.

Hume, D. (1989). “A Treatise of Human Nature”, int., by L. A. Selby-Bigge, second ed. by P. H. Nidditch, Oxford.

Kierkegard, S. (2017). Korku ve Titreme: "Diyalektik Lirik”. Çeviren: İ. Yerguz. 2. Bası. Say Yayınları. İstanbul.

Madden, E. H. (1983). "The Metaphilosophy of Common Sense", American Philosophical Quarterly, V.20, N.1, January.

Müminoğlu, K. (2016). Sosyal Kalkınmada Sosyal Felsefenin Rolü, UNIDAP Bölgesel Kalkınma Konferansı Bildiriler Kitabı. Cilt:1, 534-544.

Öztürk, A. (2019). “İmajoloji”, 3. Baskı, Elis, Ankara.

Öztürk, A. (2018). "Üniversitelerin Paradigma Sorunu ve Yeni Arayişlar", 3rd International Congress on Multidisciplinary Studies Kiev-Ukraine

Pols, E. (1979). "The Ontology of the Rational Agent", in Review of Metaphysics, 33, 1979-80.

Reid, T. (1970). "An Inquiry into the Human Mind", edited with an introduction by Duggan, T., USA.

(1969). "Essays on the Active Powers of Human Mind", int. by Brody B, M. I. T.

(1969). "Essays on the Intellectual Powers of Man”, int. by Brody B, M. I. T.

Ryle, G. (1976). “The Concept of Mind”, UK.

Rescher, N. (1970). "On the Characterisation of Actions", in "The Nature of Human Action", ed. by Brand, M, USA.

Rescher, N. (1986). (editor) "Current Issues In Teleology”, USA.

Shoemaker, S. (1972). "Self-Knowledge and Self-Identity", USA: Ithaca.

Sorley, W. R. (1951). "A History of English Philosophy”, UK.

Tüzer. A. Postmodernizm ve Tanrı'nın Ölümü: Öznenin Arkeolojisi Üzerine Bir Deneme, Milel ve Nihal, 12(2), 73-124.

UNIDAP Bölgesel Kalkınma Konferansı Bildiriler Kitabı (2016). Muş Alparslan Üniversitesi, Kalkınma Bakanlığı ve diğer paydaşlar. Cilt I-II. Mega Ofset. Erzurum. 